Volume: 13 Issue: 2 Year: 2016

\title{
Identification of expectations and encountered problems of the middle-school students participating in the sports activities
}

\author{
Menzure Sibel Yaman ${ }^{1}$ \\ Mustafa Bar ${ }^{2}$ \\ Murat Sarıkabak ${ }^{3}$ \\ Gülten Hergüner ${ }^{4}$
}

\begin{abstract}
In healthy societies, physical education and sport activities carry important roles in raising individuals. Previous scientific researches point out that physical activity is very important in the development process of the children. Therefore, children need to be supported in joining planned and systematic physical education and sport activities in both family and school life, beginning at very young ages. Every possibility should be offered to the children for performing sport activities healthily in the habitat while also taking precautions.

The purpose of the study is to identify the expectations of the middle-school students and the problems they encounter when attending sport activities in their family and school lives. The data was collected through a survey developed by the researchers. A descriptive method with the aim of revealing the current situation was used in the study. The population of this study consisted of 2500 students, studying in the 5th, 6th, 7th and 8th grades of the middle-school. Two middle schools from the schools within the Sakarya province were selected through a random selection method. The survey was applied to a total amount of 400 volunteer students that were selected as the sample group and studied in these schools. The SPSS 15.0 for Windows software was used for the data analysis. Frequency analysis was used in order to determine the quantity and percentage distributions of the demographic information of the participants. On the other hand, chi-square analysis was used for the comparison of the problems and expectations related to family and school life in regards to the demographic variables. The level of significance in the chi-square analysis was specified as $\mathrm{p}<0,05$.

As a result of the study, in relation to the family and school life, the male students were found to have more problems and expectations regarding the participation in physical education and sport activities, when compared to female students. In addition to this, the students who participated in physical education and sport activities regularly seemed to have bigger expectations and more problems with their families.

The problems and expectations of participating students regarding the family and school life were identified and suggestions for possible solutions were presented. The study is hoped to be beneficial for the field.
\end{abstract}

Keywords: Physical Education and Sport; Family; School; Problem; Expectation.

\footnotetext{
${ }^{1}$ Gazi Üniversitesi, Sağlık Bilimleri Enstitüsü Beden Eğt. Ve Spor ABD, msibelyaman@hotmail.com

2 Sakarya Üniversitesi, Eğitim Bilimleri Enstitüsü Beden Eğt. ve Spor Öğr. ABD, barmustafa@gmail.com

3 Arş. Gör., Sakarya Üniversitesi, Spor Bilimleri Fakültesi, msarikabak@sakarya.edu.tr

${ }^{4}$ Doç. Dr., Sakarya Üniversitesi, Spor Bilimleri Fakültesi, herguner@sakarya.edu.tr
} 
Yaman, M. S.., Bar, M., Sarıkabak, M. \& Hergüner, G. (2016). Identification of expectations and encountered problems of the middle-school students participating in the sports activities. Journal of Human Sciences, 13(2), 3044-3056. doi:10.14687/jhs.v13i2.3683

\section{Introduction}

Many scholars have performed physical education and sport researches and these studies allowed descriptions of sport and physical education with different perspectives. Some of these are included in our study. This study is aimed at identifying the problems in the family and school lives along with expectations regarding physical education and sport activities. Therefore, the descriptions, texts and opinions given below are important in terms of shedding light onto our study.

Due to the fact that education is interested in human integrity and takes the human as a whole, the main approach of physical education should also be considering the human as a whole. It is known that while physical education realizes these aims, it uses the moves that are in the human nature, as the tools (Balcığlu et al., 2003:13-20).

Physical education is to ensure the physical, spiritual and intellectual development of the individual in accordance with the main principles of the National Education. Game, gymnastics and sport activities as a whole are the reflections of the individual being physically solid (Arslan, 1979:102).

Physical education is a broad based activity which includes all of the sport exercises, gymnastics and games alongside with the physical health and the spiritual health of the individual, aimed at improving the physical talents and dependent on flexible rules that vary in accordance with environmental conditions and the features of the participants when required (Yamaner, 2001).

Turgut (1993) states that "Physical education must bear the aim of the children adopting and personally exploring with joy. On the other hand, it needs to emphasize social learning and education strongly for the present and the future as the social responsibility that is prominent towards the environment".

The physical education activities are a system of activities that involve the individual to participate within the framework of the physical health and competence they possess while expressing themselves, improving the structure and function of their bodies, aimed to improve the joints and muscles didactically with balance and control, teaching them how to spend the physical energy in the job field after the school epoch and in the recreational activities, therefore teaching the movement of the organs with control and in accordance with certain methods (Öztürk, 1982:9).

Sport activities allow the bone and muscle development to be healthy while also regulating the blood flow in all around the body and helping the improvement of body health of the children. While the children learn about their talents in the mental development, they improve their reflexes and thinking abilities and gain the habit of making quick decisions, applying the decision and taking responsibility regarding the outcomes of the decision they have made. The children gain the ability of group acquisition with their friends, the ability to express themselves while socializing and most importantly understanding to win and lose while gaining the ability to accept both (Erkal et al., 1998:120-123).

According to Keten (1974), sport is the conversion of the societal and characteristic personality into a competition that is systematic, fair, within certain rules, physics and morale, while establishing a reciprocal relation between the urge of struggling and determination to succeed, that are the features of human nature, and the nature and social structures, or on the other hand, the form that is the result of a conversion of the activities that ensure the individual's physical and mental health and are related to the balanced development of the structure, into success and competition. 
Yaman, M. S.., Bar, M., Sarıkabak, M. \& Hergüner, G. (2016). Identification of expectations and encountered problems of the middle-school students participating in the sports activities. Journal of Human Sciences, 13(2), 3044-3056. doi: $10.14687 /$ ihs.v13i2.3683

The habit of performing regular sport activities varies in a wide perspective of options such as the aim of the individuals who turn to sport, resting and spending time peacefully, conserving the health, being strong, acquiring a social environment or earning money )Amman, 2005). In this sense, Hergüner (2015) states that, "Sport consists of psychomotor activities that are educational, socializing, performance boosting, and are evaluated through the use of numbers and the units of measure such as weight, meter and time, while depending on mental and physical competition, requiring planned work and obedience of the rules, and that are performed with or without tools as individually or in a team setting with different aims and through the use of various fields" (Hergüner at. all, 20016).

Children, by nature, like to test themselves among their peers and enjoy competing with them. The families are expected to support them in this process. As the second close environment, the children that are talented in various sport branches are expected to be given chances for testing themselves with the competitions organized at schools. Moreover, the love of sport among other features such as the durability, velocity, ability and movement of the children should be improved through various applications aimed at productivity (Muratli, 1997).

The improvement of the training skills of the children, identification of their talents and finding the successful sportsmen and raising them are crucial concerning the future of our sports. Therefore, the families need to believe all of the benefits of sports and pay attention to the collaboration between schools and families. In short, the families need to possess the sport culture in order to educate their children on this subject. The families that have enough knowledge will encourage their children to perform sport activities in the healthiest manner and support them (Hergüner, 1991:91).

Abilities, special talents, societal relations can also determine the child's ability to adapt. The child, who has spent their previous periods in rapport, can solve an encountered problem easier. Children attending sportive activities and interactions, performing lifestyle changes, along with changes in the physical or social environments are seen as important tools in dealing with nonoccurrence (Rokach, 1989:39-54).

Participating in sportive games as a team member helps children to develop emotions such as helping each other, working as a team, respecting other team members and the rules of the game (Zülkadiroğlu, 2002).

The children seeing family members besides them while in the sport activities will lead to an increase in the matters shared with the family and strengthened ties with the family. In these situations, the duties that fall onto the family members can be exemplified as supporting the children, positive criticism while also showing appreciation for being in a beneficial activity that is sport (Öztürk, 1998).

There are also important responsibilities for the schools that are the home for education. These responsibilities include spreading, endearing and encouraging physical education and sport activities. A wide base in individual, school and mass sports can be formed in case of love of sport being initiated in family as an element of primary education, later on supported, and encouraged in the schools (Hergüner, 1992:61).

In this framework, a raise is expected in the amount of participating children in physical education and sport activities. Physical education and sport activities contribute to the individuals' physical and mental education positively and therefore affect the individual to get to know and improve 
Yaman, M. S.., Bar, M., Sarıkabak, M. \& Hergüner, G. (2016). Identification of expectations and encountered problems of the middle-school students participating in the sports activities. Journal of Human Sciences, 13(2), 3044-3056. doi:10.14687/jhs.v13i2.3683

themselves within the activities. These acquisitions guide individuals to be healthy in their social lives and take an active role within the society. This on the other hand will conduce them to express their problems in their family and school lives, find solutions for these problems, reveal their expectations and perform researches in order to satisfy these expectations. With this study which is conducted with the dependence on this point of view, the aim was to draw attention the problems and expectations of the students studying in the middle schools regarding the physical education and sport activities in which they participate, along with the problems and expectations in their family and school lives and to find solutions regarding these matters.

\section{Method}

A descriptive method was used in the study in order to define the current situation.

The development of the tool used in the study: At the first stage, 100 volunteer students studying in the 5th, 6th, 7th and 8th grades of two of the middle-schools that were selected through a random selection method were asked to write on an open ended survey, the problems they encountered and the expectations they had regarding the family and school lives in their participation in the physical education and sport activities. The problems and expectations that they have stated using their own words were acquired through the use of the open-ended survey. The acquired expectations were reviewed, described cognizably and turned into closed end, two-option (Yes-No) questionnaires. Upon receiving the domain experts, the test was applied to the same individuals through the test-retest method. Upon seeing that the questionnaire "The Problems and Expectations the Students Encounter/Have in Their Family and School Lives regarding Their Participation in Physical Education and Sport Activities" that was developed by the researchers was comprehensible, it was augmented and applied to the sample group studying in the 5th, 6th, 7th and 8th grades in the chosen middle-schools. 400 questionnaires that were filled in full were accepted to be valid.

The Purpose of the Study: Identifying the problems and expectations of the students studying in the middle schools, regarding their school and family lives in their participation in the physical education and sport activities, and comparing this data with certain demographic information.

The Problem of the Study: What are the problems and expectations the middle-school students have on their family and school lives while participating in the physical education and sport activities? Do the problems and expectations of the students vary depending on the students' gender and frequency of performing sport activities?

\section{Sub-Problems of the Study:}

1: Do their problems differ depending on their gender and frequency of participating in sport activities?

2: Do their expectations differ depending on their gender and frequency of participating in sport activities?

\section{Hypotheses:}

H1: Their problems differ depending on their gender and frequency of participating in sport activities.

H2: Their expectations differ depending on their gender and frequency of participating in sport activities.

The tables were created in accordance with these results and the comments were placed underneath. 
Yaman, M. S.., Bar, M., Sarıkabak, M. \& Hergüner, G. (2016). Identification of expectations and encountered problems of the middle-school students participating in the sports activities. Journal of Human Sciences, 13(2), 3044-3056. doi:10.14687/jhs.v13i2.3683

The Importance of the Study: In this study, the purpose was to identify the problems and expectations the middle-school students have in their school and family lives during their participation process in the physical education and sport activities. The results that were achieved through the data are considered to be important with the hope that the results will reach the families, the Ministry of National Education, the Ministry of Youth and Sports, Head Council of Education and Morality, among other relevant departments, in order to solve the problems and meet the expectations of the students. The results of the scientific studies, which are performed for providing a higher quality service in the structuring of the education planning and sportive services, can be directive. It is hoped that the physical education courses of the students studying in the middle-schools will be more productive and fit for the purpose, allowing the adoption of the notion of positive sport in the schools and families by identifying the problems and expectations in their family and school lives regarding their ability to perform healthily at subjects and sport activities, creating appropriate sport environments and developing education programs, while on the other hand contributing to similar future studies in the field.

The Population and the Sample of the Study: The population of the study consisted of 2500 students, which studied, in the 5th, 6th, 7th and 8th grades of the middle-schools in the academic year 2013-2014 in the Sakarya district. The middle schools in the Sakarya district that are in the midst of the city life and have many students were included within the scope of the study. 400 volunteer students studying in the 5th, 6th, 7th and 8th grades of the middle-school which was selected through the random selection method, constituted the sample group.

The Questionnaire of the Study: The Questionnaire titled "The Problems and Expectations the Students Encounter/Have in Their Family and School Lives regarding Their Participation in Physical Education and Sport Activities" which was developed by the researchers of the study was used for the study. The Questionnaire was applied to 500 volunteer students who studied in the 5th, 6th, 7th and 8th grades of the middle school, which was selected through the random selection method, and 400 of them, which were filled in completely, were accepted as valid entries.

The Statistical Analyses of the Study: The packaged program SPSS 15.0 for Windows was used for the analysis of the data that was collected. Frequency analysis was used in the identification of the percentage distributions and numbers of the demographic information of the participants. The demographic variables dependent comparison of the problems and expectations in the school and family lives of the participants' while partaking in the physical education and sport activities was performed with the help of the chi-square analysis. The level of significance was determined as $\mathrm{p}<0,05$ in the chi-square analysis.

\section{Findings}

Table 1. Frequency and Percentage Distributions of the Participants regarding Their Demographic Information

\begin{tabular}{|l|l|l|l|}
\hline Variables & Sub Variables & F & $\mathbf{0}$ \\
\hline \multirow{2}{*}{ Gender } & Female & 213 & 53,3 \\
\cline { 2 - 4 } & Male & 187 & 46,8 \\
\hline \multirow{3}{*}{$\begin{array}{l}\text { Frequency of participating } \\
\text { in the branch of physical } \\
\text { education and sport activity }\end{array}$} & Every day & 49 & 12,3 \\
\cline { 2 - 4 } \begin{tabular}{l} 
interested \\
\cline { 2 - 4 }
\end{tabular} & $3-5$ days a week & 55 & 13,8 \\
\cline { 2 - 4 } & 2 days a week & 79 & 19,8 \\
\cline { 2 - 4 } & Iday a week & 101 & 25,3 \\
\hline
\end{tabular}


Yaman, M. S.., Bar, M., Sarıkabak, M. \& Hergüner, G. (2016). Identification of expectations and encountered problems of the middle-school students participating in the sports activities. Journal of Human Sciences, 13(2), 3044-3056. doi:10.14687/jhs.v13i2.3683

When Table 1 is examined, it can be seen that 213 of the participants are female students while 187 are male. On the other hand, 49 of the participants partake in physical education and sport activities they are interested in, every day, while for 55 of them it is 3-5 days a week, 79 participate in 2 days of the week, 101 only 1 day a week and 116 participate irregularly.

Table 2. The Gender Based Comparison of the Problems the Participants Encounter Regarding Their Family Life during Their Participation in the Physical Education and Sport Activities

\begin{tabular}{|c|c|c|c|c|c|c|}
\hline \multirow{2}{*}{ Problems } & \multirow{2}{*}{ Responses } & \multirow{2}{*}{$\begin{array}{l}\text { Descriptive } \\
\text { Statistics }\end{array}$} & \multicolumn{2}{|l|}{ Gender } & \multirow{2}{*}{ Total } & \multirow{2}{*}{ Significance } \\
\hline & & & Female & Male & & \\
\hline \multirow{6}{*}{$\begin{array}{l}\text { My family tells me that } \\
\text { I need to finish my } \\
\text { school first and I can } \\
\text { deal with sports later }\end{array}$} & \multirow{3}{*}{ Yes } & $\mathrm{F}$ & 69 & 100 & 169 & \multirow{6}{*}{$\begin{array}{l}x^{2}=18,13 \\
d f=1 \\
p=, 000\end{array}$} \\
\hline & & (\%)Line & 40,8 & 59,2 & 100,0 & \\
\hline & & $(\%)$ Column & 32,4 & 53,5 & 42,3 & \\
\hline & \multirow{3}{*}{ No } & $\mathrm{F}$ & 144 & 87 & 231 & \\
\hline & & $(\%)$ Line & 62,3 & 37,7 & 100,0 & \\
\hline & & $(\%)$ Column & 67,6 & 46,5 & 57,8 & \\
\hline \multirow{6}{*}{$\begin{array}{l}\text { My family does not } \\
\text { accept sport as an } \\
\text { occupation }\end{array}$} & \multirow{3}{*}{ Yes } & $\mathrm{F}$ & 84 & 81 & 165 & \multirow{6}{*}{$\begin{array}{l}x^{2}=, 618 \\
d f=1 \\
p=, 432\end{array}$} \\
\hline & & $(\%)$ Line & 50,9 & 49,1 & 100,0 & \\
\hline & & $(\%)$ Column & 39,4 & 43,3 & 41,3 & \\
\hline & \multirow{3}{*}{ No } & $\mathrm{F}$ & 129 & 106 & 235 & \\
\hline & & (\%)Line & 54,9 & 45,1 & 100,0 & \\
\hline & & (\%)Column & 60,6 & 56,7 & 58,8 & \\
\hline \multirow{6}{*}{$\begin{array}{l}\text { My family thinks that } \\
\text { physical education and } \\
\text { sport activities affect } \\
\text { my grades negatively }\end{array}$} & \multirow{3}{*}{ Yes } & $\mathrm{F}$ & 57 & 70 & 127 & \multirow{6}{*}{$\begin{array}{l}x^{2}=5,23 \\
d f=1 \\
p=, 022\end{array}$} \\
\hline & & (\%)Line & 44,9 & 55,1 & 100,0 & \\
\hline & & $(\%)$ Column & 26,8 & 37,4 & 31,8 & \\
\hline & \multirow{3}{*}{ No } & $\mathrm{F}$ & 156 & 117 & 273 & \\
\hline & & (\%)Line & 57,1 & 42,9 & 100,0 & \\
\hline & & (\%)Column & 73,2 & 62,6 & 68,3 & \\
\hline
\end{tabular}

Upon the examination of Table 2, it is seen that the problem "My family tells me that I need to first finish my school first and I can deal with sports later" $(\mathrm{p}=, 000)$ is encountered by male participants at significantly higher levels than females when compared to the problem "My family thinks that physical education and sport activities affect my grades negatively" $(p=0,22)$. According to this result, $\mathrm{H} 1$ is partially verified.

Table 3. The Comparison of the Problems Encountered Regarding the Family Life during the Participation in the Physical Education and Sport Activities in Respect to the Frequency of Dealing with Sport Activities

\begin{tabular}{|c|c|c|c|c|c|c|c|c|c|}
\hline \multirow[b]{2}{*}{$\begin{array}{l}\text { है } \\
\text { : } \\
0 \\
0 \\
0\end{array}$} & \multirow[b]{2}{*}{ 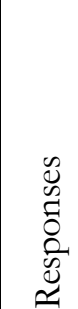 } & \multirow{2}{*}{ 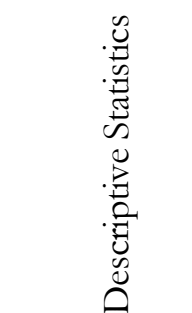 } & \multicolumn{5}{|c|}{ Frequency of dealing with sports } & \multirow[b]{2}{*}{ సٓ } & \multirow[b]{2}{*}{ 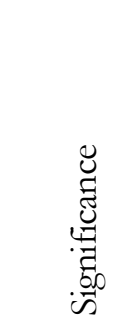 } \\
\hline & & & 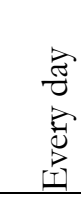 & 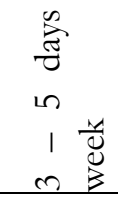 & 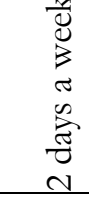 & 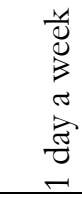 & 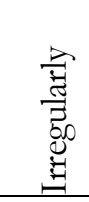 & & \\
\hline \multirow{6}{*}{$\begin{array}{l}\text { My family tells me } \\
\text { that I need to } \\
\text { finish my school } \\
\text { first and I can deal } \\
\text { with sports later }\end{array}$} & \multirow{3}{*}{ Yes } & $\mathrm{F}$ & 24 & 22 & 37 & 40 & 46 & 169 & \multirow{6}{*}{$\begin{array}{l}x^{2}=2,31 \\
d f=4 \\
p=, 678\end{array}$} \\
\hline & & (\%)Line & 14,2 & 13,0 & 21,9 & 23,7 & 27,2 & 100,0 & \\
\hline & & $(\%)$ Column & 49,0 & 40,0 & 46,8 & 39,6 & 39,7 & 42,3 & \\
\hline & \multirow{3}{*}{ No } & $\mathrm{F}$ & 25 & 33 & 42 & 61 & 70 & 231 & \\
\hline & & (\%)Line & 10,8 & 14,3 & 18,2 & 26,4 & 30,3 & 100,0 & \\
\hline & & $(\%)$ Column & 51,0 & 60,0 & 53,2 & 60,4 & 60,3 & 57,8 & \\
\hline
\end{tabular}


Yaman, M. S.., Bar, M., Sarıkabak, M. \& Hergüner, G. (2016). Identification of expectations and encountered problems of the middle-school students participating in the sports activities. Journal of Human Sciences, 13(2), 3044-3056. doi:10.14687/jhs.v13i2.3683

\begin{tabular}{|c|c|c|c|c|c|c|c|c|c|}
\hline \multirow{6}{*}{$\begin{array}{l}\text { My family does } \\
\text { not accept sport as } \\
\text { an occupation }\end{array}$} & \multirow{3}{*}{ Yes } & $\mathrm{F}$ & 20 & 27 & 36 & 40 & 42 & 165 & \multirow{6}{*}{$\begin{array}{l}x^{2}=3,33 \\
d f=4 \\
p=, 503\end{array}$} \\
\hline & & (\%)Line & 12,1 & 16,4 & 21,8 & 24,2 & 25,5 & 100,0 & \\
\hline & & $(\%)$ Column & 40,8 & 49,1 & 45,6 & 39,6 & 36,2 & 41,3 & \\
\hline & \multirow{3}{*}{ No } & $\mathrm{F}$ & 29 & 28 & 43 & 61 & 74 & 235 & \\
\hline & & (\%)Line & 12,3 & 11,9 & 18,3 & 26,0 & 31,5 & 100,0 & \\
\hline & & $(\%)$ Column & 59,2 & 50,9 & 54,4 & 60,4 & 63,8 & 58,8 & \\
\hline \multirow{6}{*}{$\begin{array}{l}\text { My family thinks } \\
\text { that physical } \\
\text { education and } \\
\text { sport activities } \\
\text { affect my grades } \\
\text { negatively }\end{array}$} & \multirow{3}{*}{ Yes } & $\mathrm{F}$ & 17 & 24 & 32 & 30 & 24 & 127 & \multirow{6}{*}{$\begin{array}{l}x^{2}=13,32 \\
d f=4 \\
p=, 010\end{array}$} \\
\hline & & (\%)Line & 13,4 & 18,9 & 25,2 & 23,6 & 18,9 & 100,0 & \\
\hline & & $(\%)$ Column & 34,7 & 43,6 & 40,5 & 29,7 & 20,7 & 31,8 & \\
\hline & \multirow{3}{*}{ No } & $\mathrm{F}$ & 32 & 31 & 47 & 71 & 92 & 273 & \\
\hline & & (\%)Line & 11,7 & 11,4 & 17,2 & 26,0 & 33,7 & 100,0 & \\
\hline & & $(\%)$ Column & 65,3 & 56,4 & 59,5 & 70,3 & 79,3 & 68,3 & \\
\hline
\end{tabular}

When the Table 3 is examined, it can be said that the frequency of the problem "My family thinks that physical education and sport activities affect my grades negatively" occurring shows a statistically significant difference in contrast to the participants' amount of weekly days in which they perform physical education and sport activities $(\mathrm{p}=, 010)$. According to this result, H1 is partially verified. The participants who perform sport activities in 3-5 days a week and 2 days a week encounter this problem more often. The occurrence of other problems related to the family life did not show any statistically significant differences related to the amount of weekly days in which the participants performed sport activities $(p>0,05)$.

Table 4. The Comparison of the Encountered Problems Related to the School Life during the Participation in the Physical Education and Sport Activities concerning the Participants' Gender

\begin{tabular}{|c|c|c|c|c|c|c|}
\hline \multirow{2}{*}{ Problems } & \multirow{2}{*}{ Responses } & \multirow{2}{*}{$\begin{array}{l}\text { Descriptive } \\
\text { Statistics }\end{array}$} & \multicolumn{2}{|l|}{ Gender } & \multirow{2}{*}{ Total } & \multirow{2}{*}{ Significance } \\
\hline & & & Female & Male & & \\
\hline \multirow{6}{*}{$\begin{array}{l}\text { I am not able to } \\
\text { allocate enough } \\
\text { time } \\
\text { studying. }\end{array}$} & \multirow{3}{*}{ Yes } & $\mathrm{F}$ & 44 & 56 & 100 & \multirow{6}{*}{$\begin{array}{l}x^{2}=4,58 \\
d f=1 \\
p=, 032\end{array}$} \\
\hline & & $(\%)$ Line & 44,0 & 56,0 & 100,0 & \\
\hline & & (\%)Column & 20,7 & 29,9 & 25,0 & \\
\hline & \multirow{3}{*}{ No } & $\mathrm{F}$ & 169 & 131 & 300 & \\
\hline & & $(\%)$ Line & 56,3 & 43,7 & 100,0 & \\
\hline & & $(\%)$ Column & 79,3 & 70,1 & 75,0 & \\
\hline \multirow{6}{*}{$\begin{array}{l}\text { The school does } \\
\text { not value } \\
\text { physical } \\
\text { education and } \\
\text { sport activities } \\
\text { enough. }\end{array}$} & \multirow{3}{*}{ Yes } & $\mathrm{F}$ & 100 & 88 & 188 & \multirow{6}{*}{$\begin{array}{l}x^{2}=, 00 \\
d f=1 \\
p=, 982\end{array}$} \\
\hline & & $(\%)$ Line & 53,2 & 46,8 & 100,0 & \\
\hline & & (\%)Column & 46,9 & 47,1 & 47,0 & \\
\hline & \multirow{3}{*}{ No } & $\mathrm{F}$ & 113 & 99 & 212 & \\
\hline & & (\%)Line & 53,3 & 46,7 & 100,0 & \\
\hline & & (\%)Column & 53,1 & 52,9 & 53,0 & \\
\hline \multirow{6}{*}{$\begin{array}{l}\text { The school is } \\
\text { lacking sport } \\
\text { facilities and } \\
\text { equipment }\end{array}$} & \multirow{3}{*}{ Yes } & $\mathrm{F}$ & 79 & 73 & 152 & \multirow{6}{*}{$\begin{array}{l}x^{2}=, 16 \\
d f=1 \\
p=, 698\end{array}$} \\
\hline & & (\%)Line & 52,0 & 48,0 & 100,0 & \\
\hline & & (\%)Column & 37,1 & 39,0 & 38,0 & \\
\hline & \multirow{3}{*}{ No } & $\mathrm{F}$ & 134 & 114 & 248 & \\
\hline & & $(\%)$ Line & 54,0 & 46,0 & 100,0 & \\
\hline & & (\%)Column & 62,9 & 61,0 & 62,0 & \\
\hline
\end{tabular}

Upon the examination of Table 4 , it is seen that there is a statistically significant difference between the responses the female and male students have given to one of the school related problems that is "I am not able to allocate enough time for studying" ( $p=, 032)$. According to this result, H1 is partially verified. It is seen that the male participants encounter this problem more often. No statistically significant difference was found between the responses of female and male students regarding other problems related to the school life $(\mathrm{p}>0,05)$. 
Yaman, M. S.., Bar, M., Sarıkabak, M. \& Hergüner, G. (2016). Identification of expectations and encountered problems of the middle-school students participating in the sports activities. Journal of Human Sciences, 13(2), 3044-3056. doi:10.14687/jhs.v13i2.3683

Table 5. The Comparison of the Problems Encountered Regarding the School Life during the Participation in the Physical Education and Sport Activities in Respect to the Frequency of Dealing with Sport Activities

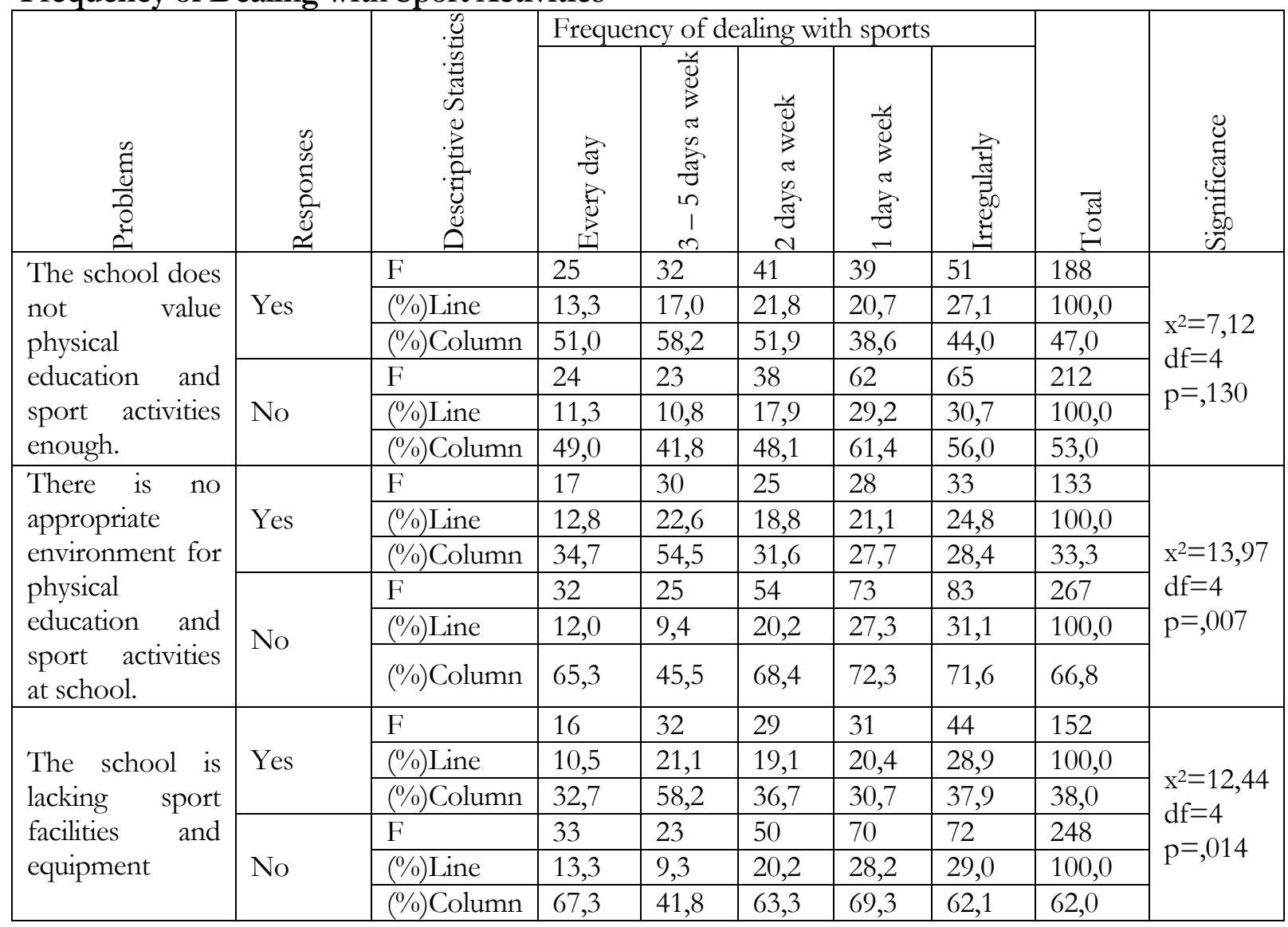

When the Table 3 is examined, it is seen that the problem "The school is lacking sport facilities and equipment" $(p=0,14)$ that is related to the school life shows significant differences in the participants who are performing physical education and sport activities 3-5 days weekly and this problem is encountered more often by these participants. According to this result, H1 is partially verified. The occurrence of the other problem however does not differ significantly in accordance with the duration of weekly physical education and sport activities the participants perform $(\mathrm{p}>0,05)$.

Table 6. The Gender Based Comparison of the Expectations the Participants Have Regarding Their Family Life during Their Participation in the Physical Education and Sport Activities

\begin{tabular}{|c|c|c|c|c|c|c|}
\hline \multirow{2}{*}{ Expectations } & \multirow{2}{*}{ Responses } & \multirow{2}{*}{$\begin{array}{l}\text { Descriptive } \\
\text { Statistics }\end{array}$} & \multicolumn{2}{|l|}{ Gender } & \multirow{2}{*}{ Total } & \multirow{2}{*}{ Significance } \\
\hline & & & Female & Male & & \\
\hline \multirow{6}{*}{$\begin{array}{l}\text { My family needs to support } \\
\text { me in participating in } \\
\text { physical education and } \\
\text { sport activities }\end{array}$} & \multirow{3}{*}{ Yes } & $\mathrm{F}$ & 162 & 137 & 299 & \multirow{6}{*}{$\begin{array}{l}x^{2}=, 412 \\
d f=1 \\
p=, 521\end{array}$} \\
\hline & & $(\%)$ Line & 54,2 & 45,8 & 100,0 & \\
\hline & & $(\%)$ Column & 76,1 & 73,3 & 74,8 & \\
\hline & \multirow{3}{*}{ No } & $\mathrm{F}$ & 51 & 50 & 101 & \\
\hline & & $(\%)$ Line & 50,5 & 49,5 & 100,0 & \\
\hline & & $(\%)$ Column & 23,9 & 26,7 & 25,3 & \\
\hline \multirow{4}{*}{$\begin{array}{l}\text { They need to come to } \\
\text { watch the matches and } \\
\text { competitions. }\end{array}$} & \multirow{3}{*}{ Yes } & $\mathrm{F}$ & 161 & 138 & 299 & \multirow{4}{*}{$\begin{array}{l}x^{2}=, 169 \\
d f=1 \\
p=, 681\end{array}$} \\
\hline & & $(\%)$ Line & 53,8 & 46,2 & 100,0 & \\
\hline & & $(\%)$ Column & 75,6 & 73,8 & 74,8 & \\
\hline & No & $\mathrm{F}$ & 52 & 49 & 101 & \\
\hline
\end{tabular}


Yaman, M. S.., Bar, M., Sarıkabak, M. \& Hergüner, G. (2016). Identification of expectations and encountered problems of the middle-school students participating in the sports activities. Journal of Human Sciences, 13(2), 3044-3056. doi:10.14687/jhs.v13i2.3683

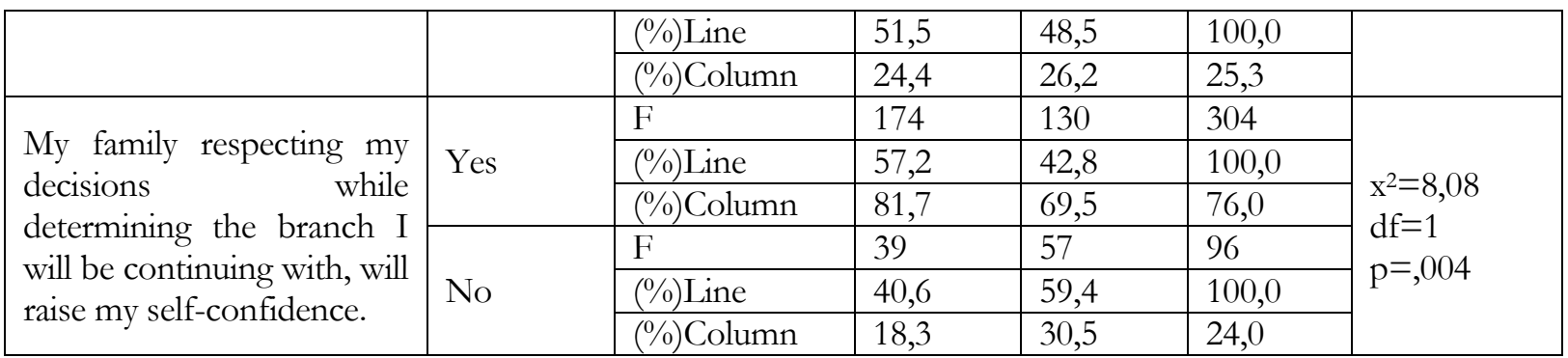

Upon the examination of Table 6, as one of the expectations listed in the participants' expectations from their family, "My family respecting my decisions while determining the branch I will be continuing with, will raise my self-confidence" shows significant differences in accordance with their gender $(p=, 004)$. According to this result, H2 is partially verified. The expectations of the males regarding the family's support is higher. The other expectation however did not significantly differ regarding the gender of the participants.

Table 7. The Comparison of the Expectations of the Participants Regarding the Family Life during the Participation in the Physical Education and Sport Activities in Respect to the Frequency of Dealing with Sport Activities

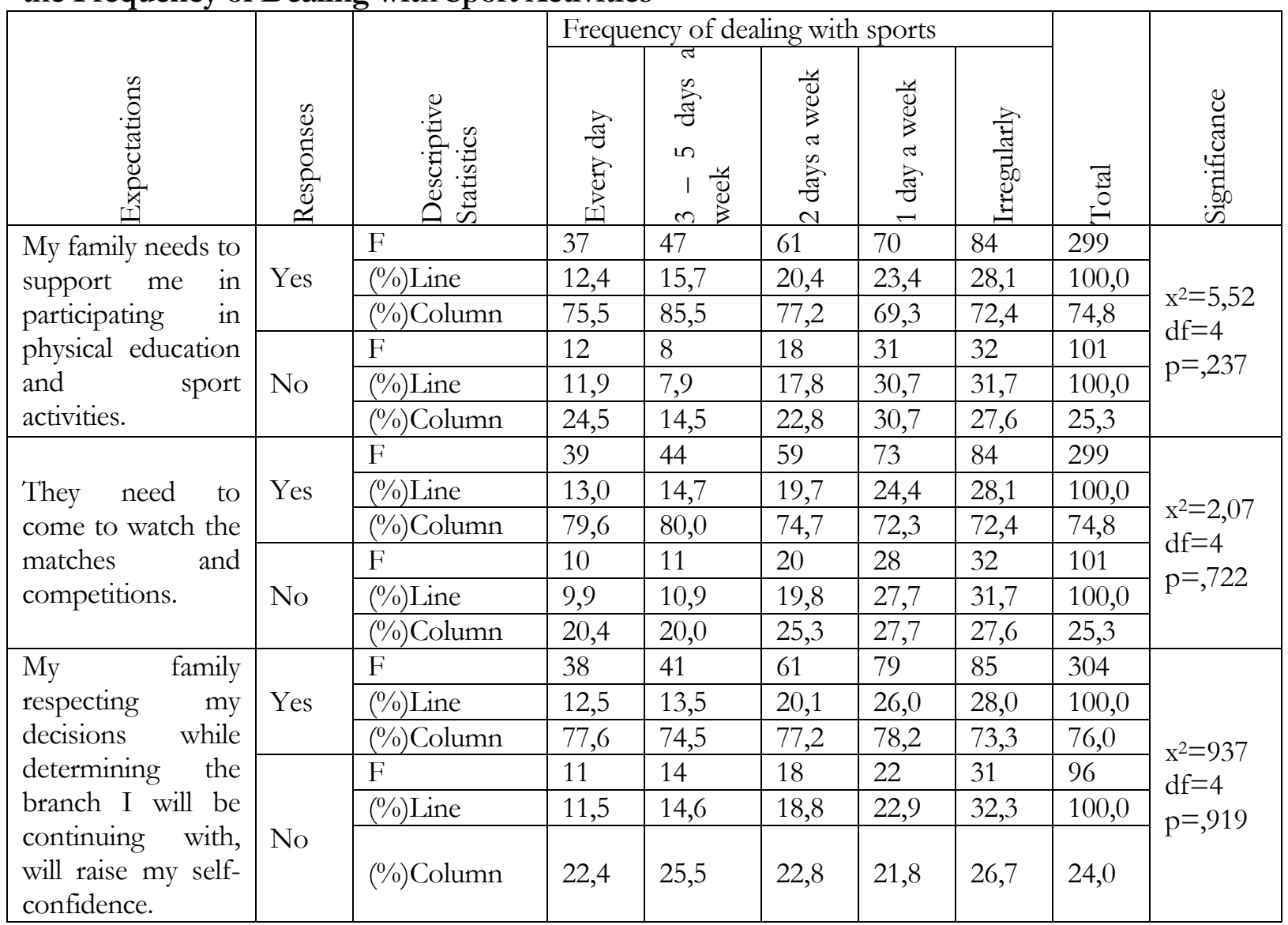

When the Table 7 is examined, it can be seen that the expectations of the participants regarding the family life do not significantly differ in relation to the frequency of participating in physical education and sport activities ( $p>0,05)$. According to this result, $\mathrm{H} 2$ is partially refused. 
Yaman, M. S.., Bar, M., Sarıkabak, M. \& Hergüner, G. (2016). Identification of expectations and encountered problems of the middle-school students participating in the sports activities. Journal of Human Sciences, 13(2), 3044-3056. doi: $10.14687 /$ ihs.v13i2.3683

Table 8. The Gender Based Comparison of the Expectations the Participants Have Regarding the School Life during Their Participation in the Physical Education and Sport Activities

\begin{tabular}{|c|c|c|c|c|c|c|}
\hline \multirow{2}{*}{ Expectations } & \multirow{2}{*}{ Responses } & \multirow{2}{*}{$\begin{array}{l}\text { Descriptive } \\
\text { Analysis }\end{array}$} & \multicolumn{2}{|l|}{ Gender } & \multirow{2}{*}{ Total } & \multirow{2}{*}{ Significance } \\
\hline & & & Female & Male & & \\
\hline \multirow{6}{*}{$\begin{array}{l}\text { Our right of } \\
\text { absenteeism should } \\
\text { not be 1sed in the } \\
\text { competitions where } \\
\text { we represent our } \\
\text { school. }\end{array}$} & \multirow{3}{*}{ Yes } & $\mathrm{F}$ & 141 & 113 & 254 & \multirow{6}{*}{$\begin{array}{l}x^{2}=1,43 \\
d f=1 \\
p=, 232\end{array}$} \\
\hline & & (\%)Line & 55,5 & 44,5 & 100,0 & \\
\hline & & (\%)Column & 66,2 & 60,4 & 63,5 & \\
\hline & \multirow{3}{*}{ No } & $\mathrm{F}$ & 72 & 74 & 146 & \\
\hline & & $(\%)$ Line & 49,3 & 50,7 & 100,0 & \\
\hline & & (\%)Column & 33,8 & 39,6 & 36,5 & \\
\hline \multirow{6}{*}{$\begin{array}{l}\text { An agreement needs } \\
\text { to be signed between } \\
\text { schools that allow } \\
\text { the school sport } \\
\text { areas to be open to } \\
\text { public and salloons } \\
\text { to be in service and } \\
\text { open at nights. }\end{array}$} & \multirow{3}{*}{ Yes } & $\mathrm{F}$ & 128 & 126 & 254 & \multirow{6}{*}{$\begin{array}{l}x^{2}=2,28 \\
d f=1 \\
p=, 131\end{array}$} \\
\hline & & $(\%)$ Line & 50,4 & 49,6 & 100,0 & \\
\hline & & (\%)Column & 60,1 & 67,4 & 63,5 & \\
\hline & \multirow[b]{3}{*}{ No } & $\mathrm{F}$ & 85 & 61 & 146 & \\
\hline & & (\%)Line & 58,2 & 41,8 & 100,0 & \\
\hline & & $(\%)$ Column & 39,9 & 32,6 & 36,5 & \\
\hline \multirow{6}{*}{$\begin{array}{l}\text { Match days should } \\
\text { be taken into } \\
\text { consideration while } \\
\text { determining the } \\
\text { exam dates in the } \\
\text { schools }\end{array}$} & \multirow{3}{*}{ Yes } & $\mathrm{F}$ & 176 & 131 & 307 & \multirow{6}{*}{$\begin{array}{l}x^{2}=8,82 \\
d f=1 \\
p=, 003\end{array}$} \\
\hline & & $(\%)$ Line & 57,3 & 42,7 & 100,0 & \\
\hline & & (\%)Column & 82,6 & 70,1 & 76,8 & \\
\hline & \multirow{3}{*}{ No } & $\mathrm{F}$ & 37 & 56 & 93 & \\
\hline & & (\%)Line & 39,8 & 60,2 & 100,0 & \\
\hline & & $(\%)$ Column & 17,4 & 29,9 & 23,3 & \\
\hline
\end{tabular}

Upon the examination of Table 8, it is inferred that the expectation "Match days should be taken into consideration while determining the exam dates in the schools" shows statistically significant differences depending on the gender of the participant $(p=, 003)$ while a bigger

percentage of the female participants have this expectation when compared to the male participants. According to this result, $\mathrm{H} 2$ is partially verified. Other school-related expectations however did not show any statistically significant differences regarding the genders of the participants $(\mathrm{p}>0,05)$. 
Yaman, M. S.., Bar, M., Sarıkabak, M. \& Hergüner, G. (2016). Identification of expectations and encountered problems of the middle-school students participating in the sports activities. Journal of Human Sciences, 13(2), 3044-3056. doi:10.14687/jhs.v13i2.3683

Table 9. The Comparison of the Expectations of the Participants Regarding the School Life during the Participation in the Physical Education and Sport Activities in Respect to the Frequency of Dealing with Sport Activities

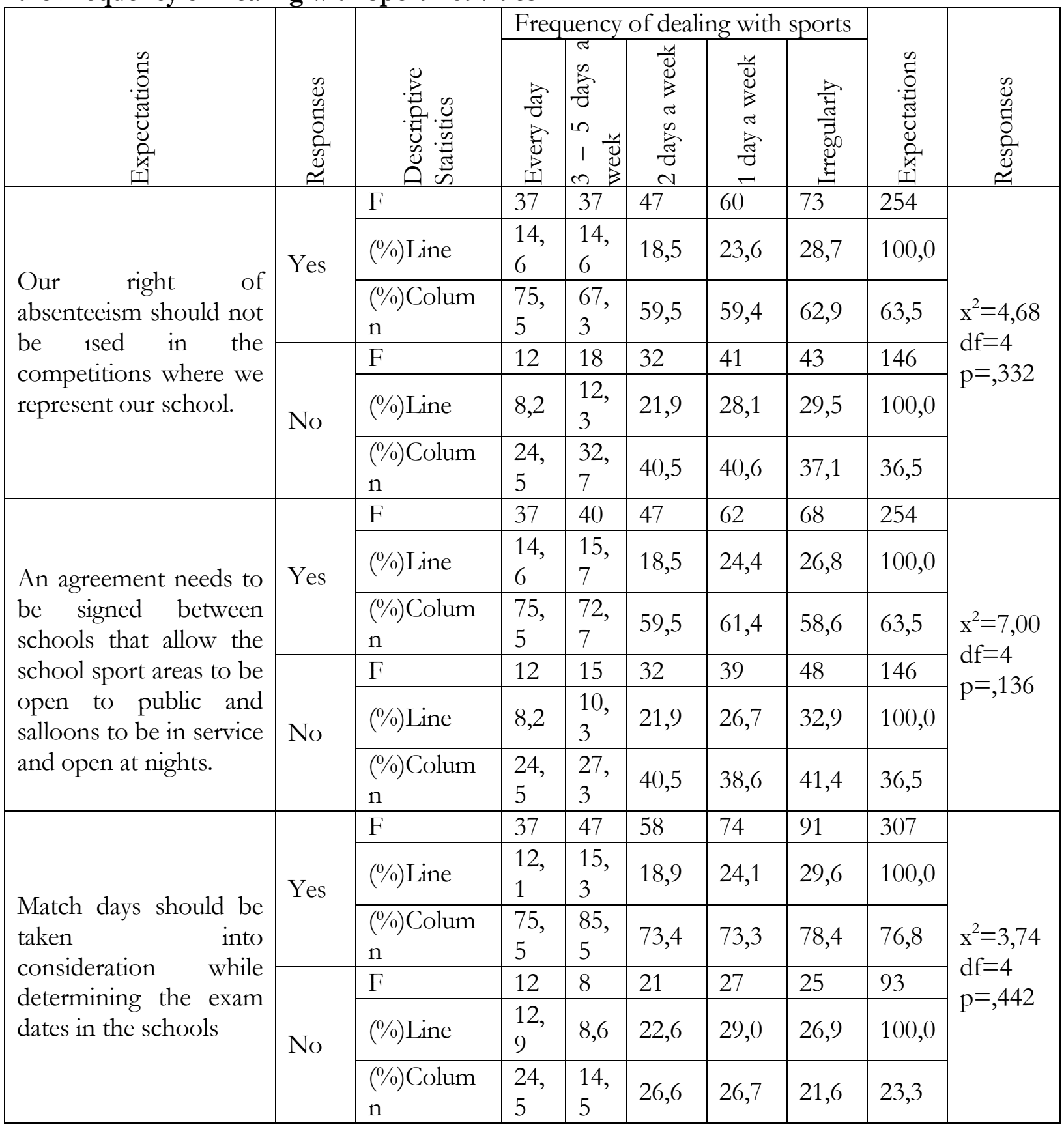

When the Table 9 is examined, it is seen that the participants' expectations from school do not show any statistically significant differences depending on the amount of days per week they spend performing physical education and sport activities $(\mathrm{p}>0,05)$. According to this result, $\mathrm{H} 2$ is partially refused.

\section{Discussion, Results And Suggestions}

213 female and 187 male students have participated in the study and 49 of them are observed to be attending the physical education and sport activity branch they are interested in on a daily basis while 55 attended 3-5 days weekly, 79 attended 2 days a week, 101 attended one day a week and 116 attended irregularly (Table 1). 
Yaman, M. S.., Bar, M., Sarıkabak, M. \& Hergüner, G. (2016). Identification of expectations and encountered problems of the middle-school students participating in the sports activities. Journal of Human Sciences, 13(2), 3044-3056. doi:10.14687/jhs.v13i2.3683

Male students are observed to be encountering "My family tells me that I need to first finish my school first and I can deal with sports later" and "My family thinks that physical education and sport activities affect my grades negatively" as part of the problems they encounter regarding their families during the period in which they participate in sport activities, more often than the female students. On the other hand, the problem of "Sport not being accepted as an occupation" is encountered by male and female students at similar levels (Table 2). This result shows similarities with the study of Doğar (2013).

The "My family thinks that physical education and sport activities affect my grades negatively" problem, which is one of the problems related to the family, is encountered more often by students who participate in sport activities 3-5 days weekly and 2 days a week (Table 3). This result showed similarities with the study of Çetin (2002).

As part of the school related problems the students encounter while attending sport activities, it is seen that male students encounter the problem "I am not able to allocate enough time for studying" more often than the female students. (Table 4).

The problems "The school does not value physical education and sport activities enough" and "The school is lacking sport facilities and equipment" which are problems related to school life are encountered at significantly higher rates by students who are participating in physical education and sport activities 3-5 days on a weekly basis (Table 5). This result shows parallelism with the study of Mamak (2010).

The male students have higher expectations regarding the expectation "My family needs to support me in participating in physical education and sport activities" in the list of expectations related to the expectations from the family in the family life (Table 6).

Among the expectations from the family related to the family life, the students who have the highest expectations of "My family needs to support me in participating in physical education and sport activities" are the students who participate in physical education and sport activities on a daily basis (Table 7). These results seem to be overlapping with the results in Hergüner (1991)'s study.

In the expectations related to school life, female students are observed to have higher expectations regarding "Match days should be taken into consideration while determining the exam dates in the schools" when compared to male students (Table 8). This result overlaps with the results in Hergüner (2001)'s study.

As a result of this study, it is seen that female students have higher expectations and encounter more problems in comparison to male students when participating in the physical education and sport activities. This can be described as stemming from the fact that female students participate in physical education and sport activities more in comparison to male students, therefore experiencing the family problems more and having more expectations from their families. On the other hand, it can be said that students who attend the physical education and sport activities regularly encounter a higher amount of problems regarding their families and have higher expectations. According to the results of the study, our $\mathrm{H} 1$ and $\mathrm{H} 2$ hypotheses are partially verified and partially refused.

Suggestions;

- The families ought to be informed regarding physical education and sports (seminars, parents' meeting and private meetings etc.), families ought to encourage students for sports, 
Yaman, M. S.., Bar, M., Sarıkabak, M. \& Hergüner, G. (2016). Identification of expectations and encountered problems of the middle-school students participating in the sports activities. Journal of Human Sciences, 13(2), 3044-3056. doi:10.14687/jhs.v13i2.3683

- The school management, counselors and families motivating and supporting the students, especially male students in participating in sports, studying and using the time efficiently,

- Students who participate in physical education and sport activities regularly, need to be supported in every aspect by the school management and families,

- Creating suitable environments for physical education and sport activities in the schools, resolving the issues regarding the sport facilities and equipment,

- Carrying out similar studies in private schools and other levels of education is suggested.

\section{References}

AMMAN MT. (2005). Kadın ve Spor. Marpa Kültür Yayınlanı, İstanbul.

ARSLAN, R. (1979). Beden Ë̈itimi Bilgileri, s.102, Ankara.

BALCIOĞLU B, ÖZBEK A, SUNGUR N. Beden eğitimi ve spor öğretmenliği öğrencilerinin değer sistemleri ve sorun çözmedeki yeterliliklerinin incelenmesi. III. Ulusal Beden Eğitimi ve Spor Öğretmenliği Olimpik Eğitim ve Spor Kültürü Sempozyumu, Uludağ Üniversitesi, Bursa, sayfa 13-20, 2003.

ÇETIN, Y. (2002). İlköğretim 4. ve 5. sme ögretmenlerinin smefta karşzlaştıklar disiplin problemleri ile ilgili görüsleri, Adana, Çukurova Üniversitesi Sosyal Bilimler Enstitüsü, Yayımlanmamış yüksek lisans tezi.

DOĞAR A.(2013) Illköğretim İkinci Kademe (6, 7 Ve 8. Sinflar) Beden Eğitimi Derslerinde Öğrencilerde Görülen Istenmeyen Davranışlar Ve Öğretmenlerin Yaklaşımlarnm Değerlendirilmesi, Erzurum, Atatürk Üniversitesi Eğitim Bilimleri Enstitüsü Eğitim Bilimleri Ana Bilim Dalı Eğitim Yönetimi, Teftişi, Planlaması Ve Ekonomisi Bilim Dalı Doktora Tezi.

ERKAL M.E., GÜVEN Ö., AYAN, D. (1998). Sosyolojik Açıdan Spor, Derya Yayınları, s.120-123, İstanbul.

HERGUNER, G., BAR, M., YAMAN, M.S., (2016). Beden eğitimi ve spor etkinliklerine katılan ortaokul öğrencilerinin aile, okul yöneticileri ve öğretmenlerden beklentilerinin belirlenmesi. International Journal of Human Sciences, 13(1), 155-168. Doi: 10.14687/ijhs.v13i1.3533

HERGÜNER, G. (1992). Ĕ̈̆tim - Spor İliskkisi, On Dokuz Mayıs Üniversitesi Eğitim Fakültesi Dergisi, Aralık, Say1 7, S.61, Samsun.

HERGÜNER, G. (1991). Cocuğmn Spora Yönelmesinde Ailenin Rolü Ve Önemi, On Dokuz May1s Üniversitesi Eğitim Fakültesi Dergisi, Sayı 6,s,91 Samsun.

HERGÜNER, G. (2001). Farkli Liselerdeki Sporcu Ögrencilerin Problem Ve Beklentilerinin Belirlenmesi Ankara Il Örneği, Basılmamış Doktora Tezi, Gazi Üniversitesi, Sağlık Bilimleri Enstitüsü, s.92, Ankara.

KETEN, M. (1974). Türkizye'de Spor, Ayyıldız Matbaas1, Ankara.

MAMAK, H. (2010). 8 Yallhk Kesintisiz Illkögretim Okullarnda Beden Eğitimi Ve Spor Derslerinin Uygulanırlyğ Ve Amaçlarna Ulaşma Düzeyi [ Konya İli Uygulaması], Ankara, Gazi Üniversitesi, Eğitim Bilimleri Enstitüsü, Beden Eğitimi Ve Spor Öğretmenliği Anabilim Dalı, Doktora Tezi.

MURATLI, S. (1997). Çocuk ve Spor. Ankara: Bağırgan Yayınevi.

ÖZTÜRK F. (1998). Toplumsal Boyutlarılla Spor, Bağırgan Yayınevi, Ankara, S., 9, 21, 48, 51-53, 61-63)

ÖZTÜRK, Ü. (1982). Orta Dereceli Okullarda Beden Ë̆itimi, Güven Matbaas1, s.9. İstanbul.

ROKACH, A., (1989). Surviving And Coping With Loneliness, Journalo Psychology,124(1),39-54.

TURGUT, I. (1993). Bedenim ve zihnim. Eğitim Kurumlarında Beden Eğitimi ve Spor II. Ulusal Sempozyumu, Manisa, sayfa 39-45,

YAMANER F.( 2001). Beden eğitimi ve sporda temel ilkeler, Hünkâr Ofset, Ekin Kitapevi, Bursa, sayfa 3-7, 10-14, 65-71.

ZÜLKADIROGLU Z. (2002).11-13 yaş grubu bireylerde temel jimnastik çallsmalarmm, sosyal yetkinlik beklentisi üzerine etkisi, Adana, Çukurova Üniversitesi, Doktora Tezi. 